\title{
A Social-constructionist, narrative understanding of the Church's morality on sex
}

\author{
J C Müller, H E Pienaar ${ }^{1}$ \\ (University of Pretoria)
}

\section{ABSTRACT \\ A social constructionist, narrative understanding of the church's sexual morality}

This article can be described as a social constructionist, narrative understanding of a group of selected South African white Christians' experience and perceptions regarding sexual morality in the context of heterosexual couples. In this article we will encounter alternative descriptions of sex, sexuality and marriage. The assertion is made that sexual morality should be understood within a relational contextual view of human interaction. This entails a shift away from act-centred, universally right or wrong sexually moral behaviour. These contentions are grounded in a thickened description of sex, sexuality and marriage, through which the thin, act-centred discourse of sex as coitus and marriage as ceremonial consent is deconstructed. A few guidelines are also being made in view of the church and parents. The authors use the metaphor of the board game "snakes and ladders" to enlighten the underlying worldview and findings, thereby situating sexual morality within the sphere of human social interaction and reality.

\section{INTRODUCTION}

Premarital sex, the topic on which everybody is bound to have an opinion! This article does not tend to answer the question as to whether it's right or wrong to engage in pre marital sex. What we are concerned with is the social constructionist, narrative understanding of heterosexual sexual morality. Donnelly (1993:171) rightly notes that sexual activity is not an easy topic to measure or study. Therefore premarital sex, being such a highly opinionated topic is only taken as a point of reference in order to talk about sexual morality. This is reflected in prior-research remarks made by some of the co-researchers, such as: "Mens kan nie seksuele moraliteit en die daad skei nie. Mens praat juis ook oor moraliteit wanneer mens die daad gebruik (as gesprekspunt). In die studie gaan dit juis vir my oor moraliteit eerder as die daad". Hauerwas (1991:125 cited in Barton 1998:376) also notes that in order to talk sensibly about sex you

1 This article is based on research conducted for a thesis submitted in partial fulfilment for the degree MA (Theol) Pastoral Family Therapy at the University of Pretoria under supervision of professor Julian Müller. 
must have available determinative practices that place such discussions in a purposive framework.

The need to talk about sexual morality seems to be comparable to the game of snakes and ladders, where the end is not a "conclusion about" or a finish line, but an "understanding of", and the next beginning of sexual morality. This metaphor will be used to elaborate on the most important findings.

\subsection{The general shift in sexual morality}

A perceptible shift in sexual morality adds to the uncertainty and confusion about where normative boundaries are now located (Gerkin 1991:12). What we do know through all the confusion is that

"...young people in many countries cohabit before marriage, and they do not accept that they are living in sin" (O'Connel 2001:122). "Despite centuries of religious and legal sanctions against premarital sex in many parts of the world, dramatic changes in sexual attitudes and behaviour have occurred during the second half of the twentieth century. Increasingly, sexual interactions have become a common and widely accepted part of romantic relationships" (Baron \& Byrne 1997:297).

In South Africa it is proposed that the cohabitation rate has escalated by $100 \%$ each year from 1980 (Rall 1984 cited by Gerdes in Louw, van Ede \& Louw 1998:586). Hanigan (1982:1) cites Andrew Greeley (1973:132) when saying that the question Christians asked about sexual morality, up until the 1960s were, "How far can we go?" Sexual expression was reserved for marriage, and even within marriage it was severely restricted and rarely discussed. He goes on to suggest that in the short space of time, twenty-five years, the answer has changed dramatically to say: you can go as far as you want. This is an indication of where the sexual morale of countless Christians is headed. Furthermore, for Carpenter (2001:76) it seems that, when asking what is considered authoritative in the lives of the majority of young people, the church comes far down the list, and for many young people it simply does not figure in their thinking or the practical daily exercise of their lives.

While on the one hand it seems plausible to talk about a general sexual shift, on the other, as social constructionist researchers we are more interested in the exceptions rather than the rules. Favouring the marginalised voices we "...choose to look at specific, contextualised details more often than grand generalizations, difference rather than similarity" (Freedman \& Combs 1996:21). This is grounded in the belief that there are limits to the ability of human beings to measure and describe the universe in any precise, absolute, and universally applicable way. We'd rather talk about the contextualised shift in sexual morality. It is contextualised in two ways: (a) looking at specific contexts of local meaning communities (heterosexual couples in their early 
twenties) and resulting from this, (b) proposing that we take up the challenge not to generalise and prescribe a universal "two in one shampoo approach" that should fit all couples and relationships.

\subsection{The contextualised shift in sexual morality}

Let us from the outset of this article make clear the voice of the co-researchers, being the preferred term in narrative research, rather than the term respondents, in which definite power inequality can be seen. We want to be faithful to the story as told by the research participants giving voice to their lived experience. Gerkin's notion of changeable boundaries (1991:27) seems to be useful in understanding their worldviews: a "...boundary is best conceived not as a line, but as a region" (Miller 1993 cited in Nel 1998:390). It's "...not the same as a barricade...". It is rather "...an area constantly renegotiated and may perhaps be better described as an area of interface.... [I]t is only with this boundary position in mind that the Christian religion or the church will be able to attend realistically to sexuality" (Nel 1998:390). Social constructionism acknowledges that the "[i]ndividual and society needs boundaries. Without boundaries individuals become chaotic personalities and end up totally dysfunctional. The same happens to organizations, communities and society" (Nel 1998:395). However, boundaries need to be open to renegotiation according to differing contexts over time. Consequently Gerkin (1991: 12) states that the churches' ministry with regard to norms and boundaries needs reframing. He thereby acknowledges the churches' failure to adequately and appropriately address this situation in the recent past. This suggests that we can never have an... "open the Book and recite the appropriate universally applicable answer to sexuality."

\subsubsection{Defining (?) problematic definitions}

To endow this article with a couple of definitions with regard to sexual morality, even for clarity's sake, will not be true to the paradigm and intention of this article. Initially definitions such as those cited by Alpaslan (1997:40) in Van Elfen (1987:21), or Bowman and Spanier (1978:21) were considered. However, this temptation to a definition of what constitutes sexual acts is the lure of a world rooted in modernistic "insights". With reference to Derrida (1997), the mere word "definition" is a modernistic idea. We should rather talk about describing sexual morality, which renders it possible to constantly renegotiate what is collectively understood as sexual morality.

As far as a description of morality is concerned, the premise on which this article is based suggests most people believe there is such a thing as morality, that our lives have a moral component, that we make real moral choices. "We have a deep primitive sense that morality is woven into the fabric of our humanness... Morality is a basic component of any human sort of life, a reality we feel surely even if we cannot define it clearly" (Smedes 1983:vii). 


\subsubsection{Being up front}

In a radically abbreviated statement the main premise of this article ${ }^{2}$ could be articulated along the following lines: That which can be described as sexually moral acts is relative to the contextual relational experiences of the specific couple, informed by the content and intent of that relationship. Along with Michel Foucault (1992 cited in Clack 1998:193), we thus acknowledge that sexuality is historically defined and contextually dependent. One relationship cannot be a carbon copy of the next.

This realisation does away with so-called objective uncontextualised knowledge about wrong or right sexual conduct in relationships. The social constructionist narrative researcher endeavours to gain insight into these unique relationships of these people, and their particular experiences of sexual morality. These and subsequent contentions are grounded in an interpretive reality which seems to have a lot to do with finding the valid criteria for "polysemy" within the fluid variety of possibilities (Mugerauer 1995:xxvii). There are criteria for shared understanding, but the validity of such criteria does not stem from objectivity, but from interpretation and co-creation between and amongst individuals and communities.

\section{PROMOTING PREMARITAL SEX?}

If this article is understood as promoting non-marital (not only including premarital, see Barnard 2000:30) casual sex, our intention is misunderstood because of the reader's worldview of modernism. The reader and the authors would be playing different ball games. We cannot play hockey with a cricket ball, however close we might think they are. Playing according to the game of research into real life stories brought about the recognition that sexual morality

2 The groundwork for this article was gathered and conducted mainly through 36 in-depth narrative interviews with couples, individuals and groups apart from numerous secondary research participant interviews. These interviews and the research process overall were based on the metaphor for fiction writing; the ABDCE approach as cited in Müller, Van Deventer and Human (2001:76-96), which in turn is based on Anne Lamott (1995:62 cited in Müller, Van Deventer \& Human 2001), following Alice Adam's formula for writing, namely Action, Background, Development, Climax and Ending. Interviews were also held with scientific groups, ranging from a sexiologist, relationship therapist, lecturers in ethics and ministers involved in the communication process. Transcribed accounts were made by the primary research participants. Different television media programmes relevant to the topic of sexual morality were also used. The whole process were governed by qualitative and narrative research principles, such as: subjective integrity, validation of data, trianuation, and critical reflection on all material from all corners of the participating bodies. Other important concepts underlying that process were co-researchers, coevolution, a not-knowing position, and transparency. 
thrives on the grey areas of human understanding. Any alternative constructions brought forth in this article should not be viewed as an inclination to a "value free" environment (Kitzinger 1987:190). In order to understand and hopefully clarify the issue of intention, something more needs to be said about the underlying worldview of this article.

\subsection{Worldview}

This article does not underscore "...principles that are true all the time and in all conditions, like laws of physics; rather, the goal is understanding of specific circumstances..." (Rubin \& Rubin 1995:38). The mechanistic approach is often ignorant of the context in which morals developed and takes morals as objective facts, disregarding the cultural differences in societies. When referring to context, it is understood as enveloping both the deeply personal-psycholoical dimension of sexuality in part related to our emotional stages of development as individuals and that which "includes the social and cultural backgrounds from which we come, along with the ways in which gender relations are constructed there" (Barton 1998:369). "This leads us to acknowledge that prohibition of premarital sex is a cultural development of the Western world, which developed over time" (Pato 1997:59 cited in Nel 1998:389; see also Thatcher 1999:113, Thom et al 1998:402, Tarnas 1996, Nel 1998:301 and Foucault 1999:118 cited in Jordan 2002:135).

We sincerely hope that the reader might learn to understand that the worldview this research is built on, does not promote the same kind of relativism that people need to be afraid of, the relativism born out of nihilism (Nel 1998:314-16).

An "anything goes" perception does not befit a social constructionist narrative understanding of life and identity. Thus, this article is not based on a "do what you like" worldview, as some might accuse postmodernism ${ }^{3}$ of. "Rather, we are motivated to examine our constructions and stories - how they have come to be and what their effects are on ourselves and others" (Freedman \& Combs 1996:35). So "[e]ven if we wanted to foster a value-neutral, 'anything goes' reality, we couldn't. One cannot make up and inhabit a completely new social reality overnight" (Freedman \& Combs 1996:36). "In some instances we talk about several generations for the beliefs, practices and institutions of our fledgling society to take on the weight of reality" (Freedman \& Combs 1996:36).

3 For the purpose of this dissertation social constructionism says the same as postmodernism, except that the prior is a better description of how we perceive the world. We could also be talking about a constitutionalist perspective, for it has to do with how we constitute ourselves in the world. 


\subsection{Practical theological positioning}

The above-mentioned frame of mind also informs this article's views on Practical Theology. In the midst of debates about sexual morality, we have to position ourselves as practical theologians.

In Practical Theology we need to situate ourselves within the lived experience of everyday Christians negotiating meaning from their experience, through which they also try to make sense of God. This is exactly what this article is based on: the lived experience of young people. Our metaphors of "narrative" and "social construction" attempt to understand human experience, and work within the matrix of meaning and interpretation of the grand Christian narrative in everyday life. Accordingly, our metaphors signify a natural progression from where we position ourselves as practical theologians, suggesting that we work from the mode of "practical wisdom" (Müller 1996:1). Practical Theology can therefore be described as an ongoing systematically structured hermeneutical process that endeavour to enlighten and renew human acts that relate to the narrative of the Christian faith community (Müller 1996:3-4).

In this case the "human acts" and the "narrative of the Christian community", can be described as the incongruence between received church teaching and the pastoral experience of this teaching in the lives of young people. As young people begin to form meaningful relationships and to explore their sexuality, many feel that the paradigm the church offers does not allow them to freely interpret and explore the gift of sexuality. "Many feel that sexuality is viewed as an abstraction rather than a contextual experience.... [I]n response, many simply reject the whole paradigm offered by the Church" (Roper 2001: 83; Cahill 2001:172).

Practical Theology is thus curious about hearing different ways in which Christians relate to the Christian cultural narrative, without compromising their core beliefs about Christianity. Thus, Practical Theology realises that values are a matter of negotiation between individuals and society at different phases of a person's development (Nel 1998:396). Some of our co-research participants might not engage in coitus mainly due to the discourse sustained by church and parents, while other "...young people in many countries cohabit before marriage, and they do not accept that they are living in sin...Waving rules at such people will not work, telling them that they face eternal fire will only evoke amusement or derision, and arguing that a return to traditional practices is the best way of doing things will fall on deaf ears. We are dealing with changed people in a developing context and face new problems that call for new methods of approach" (O'Connel 2001:121-122).

It is the duty of a practical theologian working with metaphors of "story" and "social construction" to put a question mark behind theology that does not enunciate contextualised experience of young committed couples regarding 
sexuality. We will in the following attempt to cover the most important things that our co-researchers have communicated about their stories.

To some degree we as authors have been part of their story through the research process, and you the reader has accepted the invitation to add to their story by reading these words:

"Whatever Practical Theology has to say about a given area of human endeavour, it should reflect the actual situations being addressed and not simply present an abstract model of human behaviour" (Grey \& Selling 2001:193). We thus need to pay more attention to human experience.

\section{SEXUAL MORALITY A GAME OF SNAKES AND LADDERS}

The metaphor of the well-known board game snakes and ladders proved an aid to this article and the co-researchers' understanding of sexual morality. Sexual morality has through the years, through different cultures and contexts, been printed and played on different paper. In a strange and mystical way the paper accounts for the sorrow of the losers and the joys to the victors. The paper (the worldview) on which we play is always socially constructed.

\subsection{Snakes - discourses}

Within the "game" of our metaphor, the snakes are the negative sexual discourses crawling around and influencing our understanding of sexual morality. The way in which communities play is part of their transformative story (see See Edward Bruner 1986a:25). "People are born into stories; their social and historical contexts constantly invite them to tell and remember the stories of certain events and to leave others unstoried.... '[D]iscourse' is a useful notion for understanding how this happens" (Freedman \& Combs 1996:42).

With Freedman and Combs (1996:42-3) we would describe a discourse as a system of statements, practices, and institutionalised structures, that develop and are based on shared common values. A discourse sustains a particular worldview. Freedman and Combs (1996:43) quote Rachel Hare-Mustin: "The ways most people hold, talk about, and act on a common, shared viewpoint are part of and sustain the prevailing discourses".

\subsubsection{Noteworthy discourses and altered descriptions}

\subsubsection{The discourse of parents as interpreters of Christian mora- lity}

The primary discourse surrounding the sexuality of the research participants seems to be the fear for disapproval. The disapproval of the community and parents were the primary consideration concerning sexual decisions. 
Even though the theme of church and authority i.e. religion were important to the co-researchers, precedence was given to parental influence above what the Bible is believed to say. A paraphrased argumentation of what this discourse states would be: "if my parents as committed Christian parents disprove pre marital sex, it can be taken for granted that the Bible condemns such behaviour and that it must therefore be written somewhere". Interesting enough, it sems as if the church as institution does not have such an unprecedented influence on the primary level in peoples' lives, for young people do not seem to make decisions according to church teaching. According to the co-researchers' viewpoint the church often succeeds to sustain the negative discourses about sexuality that travel via parents and community to individuals and couples. The way the team internalised beliefs surrounding sexuality therefore was through the process of reading their culture - parents, and other role models as "text" (Jerome Bruner 1986:8 cited in Freedman \& Combs 1996:16) or scripts (cultural scenarios, interpersonal scripts, and intra-psychic scripts), according to Sprecher, Barbee, and Schwartz (1995:3). Cultural scenarios inform individuals to the when, where, how, why and with whom to do sexual things (Carpenter 2001:38).

We now proceed with an exposition of even more discomforting discourses.

\subsubsection{Discourses about what sex really is}

The narrow understanding, which prevails in all sexual discourses without exception, is that sex equals coitus. This discourse is one of "...confusing sexuality with sex, especially when (as in our Western culture) 'sex' has the connotation of intercourse - as in to 'have sex'. This is unhelpful because it narrows down a very complex and many-sided, physicalpsychological-social-religious-political aspect of being human to questions about the 'how-when-where-why-with whom' of sexual intercourse" (Barton 1998:367). These latter questions are important, but they need to be set in the larger context of the meaning of the body and the meaning of being human (Barton 1998:369, see also Nicol 1989:167; McClintock 2001:55; Dominian 2001:16).

The bigger picture is "...that most interaction between people (of the same sex and the opposite sex) is loaded with sexual interplay, and that sexuality is constantly part of human activity, often not acknowledged and appreciated" (Nel 1998:394). Maybe we have arrived at the broadest possible understanding of sex through the words of Paul Tielicke in his Ethics of Sex, quoted by one of the co-researchers: "The way I greet you is sex". We are therefore cultural canvases of sex, and we are painting on each other through our human being and interaction. 
Further discourses state that sexual expression should be reserved for marriage, and then also its opposite: that everybody does it, so have a ball, have sex, enjoy yourself. They are both supported by a narrow understanding of sex as in "to have sex". The existence of the above paradoxically related discourses leads us to acknowledge that couples "...are caught somewhere between the culture's sexual 'do everything' and the Church's 'do virtually nothing"' (Cahill 2001:170).

This rather narrow understanding of sex is summarised by Grey \& Selling (2001:189), stating that young persons are still being told that sex is dangerous, cheap and a serious source of moral guilt, unless one is married, which somehow makes the very same acts legitimate (although not really all that nice).

\subsubsection{Discourses surrounding marriage}

The discourses about marriage are complex and differentiated. Some of the aspects are:

- The belief that marriage is a mutual consent with commitments made in the presence of family, friends and God.

- The ever more popular belief surrounding self-reliance and selfsufficiency, that in order for one to get married one must aspire to gain knowledge, if at all possible, through some kind of tertiary education. Society, and in this case local western Christian community, through its prescriptions, creates an unnatural sexual void when looking at human developmental stages that did exist neither in biblical times nor in some cultures today (Roper 2001:82).

- More often there is also a discourse that expresses peoples' belief about whether one is emotionally mature to engage in sexual relations.

- The discourse that takes for granted that marriage is forever. The reality, however, is that we have to acknowledge that marriage is no longer understood as a guarantee of permanency (Grey \& Selling 2001:195). "Like all human relationships, it is fragile and vulnerable. It is not a haven from the world, but ... a vessel that must weather the storms and calms of life. It needs fuel, supplies and constant maintenance" (Grey \& Selling 2001:195).

We can take as point of departure the description of Grey and Selling (2001:194) about what marriage is:

Marriage and the forms of sexual expression and encounter that are an intimate part of that relationship are not something that magically comes about with the public pronouncement of vows. Marriage, at least in the operative model in the Western world, is a relationship that grows from first meeting through various stages 
of friendship and intimacy, into different levels of commitment, through the trial and error of building a working relationship, into the complex reality of sharing the same home, resources, limitations and opportunities, along with the possible arrival and presence of children, into a maturity of years and the growth of their own offspring, past the thresholds and crises of partnership, parenthood, and, for a steadily increasing portion of the population, into the beginning of yet another form of commitment that can span several decades into old age and a completely different kind of relationship.

A description like this helps Christians to think about the process of marriage as God's intention, which is more than a government decalration of authenticity. Thatcher (1999:111) also emphasises that marriage is a process, rather than a clearly defined rite of passage.

As Barton (1998:376) puts it: "A strong argument for the Christian ideal of the covenant of life-long, monogamous, heterosexual marriage is that such a publicly acknowledged relationship provides a framework that allows mature sexual relationships to develop". Consequently, the wrongness of casual sex is situated in that such settings deny the full richness of what intercourse means, denying it's various expressions over time. The argument therefore is not that sex is not legitimate before marriage, but has much to do with the ethics that safeguards the character of sexual expression, ethics that underscores what Dominian calls the conditions of exclusiveness, faithfulness, commitment and permanency (Dominian 2001:19). Greenberg (1998:4) adds mutuality, compatibility and companionship, intimacy and sexuality, and primacy, and calls these scriptural essentials.

The co-researchers did not consider these as conditions for the institution of marriage, but rather for the process of marriage. A marriage, then, as institution, is the acting out of a symbol, a symbol revealing a kind of relationship already in existence.

\subsubsection{Making sense of altered descriptions. What do they mean?}

First and foremost our thinking about sex, sexuality and marriage should be enclosed by the morality of relationships. With Nel (1998:400; also Cahill 2001:170), we state that: "Sex needs to be placed within the context of both personal and public relationships. In a value system that places the sexual within the relational, the focus will be on the relationship, instead of on the sexual aspect".

Can we still subscribe to the statement: "Sex outside of marriage is wrong"? One could still acknowledge this if one wishes, but then within a broader understanding of marriage: a symbol of a relationship that has reached a level of intimacy that for the couple dictates life long partner- 
ship, a relationship constantly acting out of mutual consent. There will consequently be sexual practices in this kind of relationship that can be categorised under the description of sex even if not institutionally married. Coming back to our notion of boundaries: sex and marriage is now positioned within the area of interface between friendship and life long romantic partnership. What the actual date of consent, in front of family and friends indicates will differ from couple to couple in the future.

The theological discourse labelling all pre-marital sex as wrong and promiscuous seems to be a false interpretation of what constitutes promiscuous practices in ancient times (see Pienaar [2002] for argumentation and references). Promiscuity has much more to do with ignoring the relational boundaries in which sexual conduct should be expressed. The issues at play pertaining to sexual morality should be that of values and contextual experiences. In a conversation with Professor de Villiers he said that, from a theological point of view:

Daar sal algemene riglyne gegee moet word: a) seksuele is nie sommer net vir biologiese bevrediging nie b) vaste verhouding wat mik na 'n huwelik c) persoonlike verhouding met ' $n$ diep vlak van intimiteit moet dien as uitgangspunte. Daar sal ook gesê moet word hoekom die huwelik nog meermale die ideale ruimte skep vir 'n seksuele verhouding.

The couple should therefore constantly be aware of what progressive sexual behaviour communicates and implicates. Baron \& Byrne (1997:299) indicated that: more intimate touches communicate the perception of greater commitment. The right question would be: is the way of being sexual with each other congruent with the course of life that it dictates?

Grey and Selling (2001:194) states: "What is essential to understanding and living sexuality is love, respect, mutuality, trust and joy. Discovering one's partner and oneself is a journey of many years, thousands of encounters and uncountable details, many of which are unique to this person, this relationship and this historical and cultural setting". One might also say that the intent and content of the relationship is determinative of one's sexual behaviour.

If we remember that sex is not just coitus, and marriage not just ceremonial consent, we do not need to prescribe rules and regulations or surrender to an almost pathological fear. Therefore it is acknowledged that "...all loving relationships may be headed for the same ultimate goal in the Reign of God, the route by which they make their way is far more diverse than all the shipping lanes in all the seas of the earth" (Grey \& Selling 2001:195; Thatcher 1999:120). 
Contextual experience thus also suggests that "[t]eaching on sexuality must be grounded in values and not upon acts or functions, and not predicated exclusively upon particular patterns and structures of kinship" (Roper 2001:85). Thus, we should not blind ourselves to the so-called integrity of the marriage, as we should be listening to the integrity of the relationship of which marriage is a symbol. Therefore pre-married couples' sexual expression or intercourse should not be seen as isolated experiences (Dominian 2001:16). Sexual expression to whatever degree "...is an essential component of the ongoing interaction of the couple. The implication of this is that the morality of sexual intercourse (for this study any sexual expression) should be concerned with the understanding of it that safeguards its continuity, reliability and predictability. What sexual intercourse (expression) needs for the expression of its integrity is to be placed in an environment, which allows the free expression of its multiple meanings" (Dominian 2001:16).

\subsection{Ladders - chances to engage in our own constructions}

The telling of our stories will reveal the constructions that we encountered along our paths. In the game of snakes and ladders, the ladders in a unique way symbolises the moments that we have come across opportunities to view our own constructions and in this social process started to develop new realities over time. This happens in interaction with therapists, researchers, teachers, ministers, to name a few who all add to these opportunities.

As suggested by Freedman \& Combs (1996:35) we must ask the pragmatist's questions "How does this view affect my view of the world or my commitments to it?" We are convinced that it does not lead to "anything goes". Instead, we are unpacking our presuppositions and consequentially better exploring our commitments. The co-researchers felt that these conversations helped them to gain sensitivity for other people's lived experience, and to locate sexuality within relations and context. In such a way much needed conversation were opened up.

It is thus important to acknowledge our own path leading to our constructions of reality built around certain favoured discourses: educational, communal, but in the case of the authors: especially theologically. Our own stories situate us in certain theological, communal, and educational discourses. Not being aware of the snakes (discourses) in our lives, closes down options and conversation instead of giving new options (Freedman \& Combs 1996). Being aware of our constructions helped us to decide carefully how to act. "The issues of deciding, of choosing, and of examining the effects of our choices are central..." to the groundwork of this article (Freedman \& Combs 1996:35).

Ladders also seem to present themselves as the awareness of one's own voice. "Every writer has his own voice, and it is up to him to find it and use it with authority. That voice comes through as male or female, child or adult, humorous or serious, but behind it, within it, is the 
author's brooding presence, his vision of life. He describes the world from his point of view" (Marjorie Franco, cited in Hobbs 1998:71).

\subsection{Throwing the dice and moving the pieces - contextual expe- rience, constructions, and interaction}

While ladders are an indication of social constructions, it is still rather static. It does not need to be seen in that way. Living can be seen as the process of playing and rolling the dice and moving the pieces. It was in the playing, the interaction that we realised that "...moral decisions are not neutral and objective, but are culturally and contextually informed" (Nel 1998:388; Freedman \& Combs 1996:32). Rolling the dice gives rise to contextual experience carrying meaning. According to our understanding "...meaning is at once a personal, relational, and cultural achievement" (White 2000:9; Gergen 1999:131). Meaning is an "...emergent property of coordinated action" (Gergen 1999:145). Essential truths easily become legalistic, with the result that "...[w] hile modernist thinkers tend to be concerned with facts and rules, postmodernists are concerned with meaning" (Freedman \& Combs 1996: 22). "Meaning is not carried in a word by itself, but by the word in relation to its context, and no two contexts will be exactly the same. Thus the precise meaning of any word is always somewhat indeterminate, and potentially different, it is always something to be negotiated between two or more speakers or between a text and a reader" (Freedman \& Combs 1996:29).

\section{DEAR ME. CLARE GEE AND PARENT}

These subsequent few sentences, addressed to the clergy as representatives of the church and parents, seem vital in doing justice to the "will" of the co-research participants.

\subsection{Clergy}

Although McClintock (2001:10) states that congregations are rethinking their definitions of marriage and family in light of cultural acceptance of non-married, long-term partnerships, this seems to rarely be the case in our immediate culture. Over against the above testimony "[w]hen the church assigns itself a greater role than it in reality has, God-fearing individuals frequently simply ignore its pronouncements (The reaction of many committed Catholics to the church's teaching on contraceptives is one example)... [M] any committed Christians do not abide by the church's teaching on premarital sex or homosexuality" (Nel 1998:391).

This article would like to propose the involvement of the church in the facilitation process. An own value system which evolves in peoples' lives may prove to be invaluable regarding sexual decisions. This includes the churches acceptance that in value formation, experiential social learning is crucial. How can the churches be involved in this faci- 
litation process? By opening up conversation with the people's real practical life accounts and narratives. In this way the process of examining own constructions will come to the fore, and will prove to be invaluable.

The church needs to take a good look at its religious perceptions. Nelson (1996:214 cited by Hayes 1998:245-246 from Thatcher \& Stuart eds. 1996), identifies "seven signs that mark a paradigmatic shift in the religious perceptions of human sexuality". These include a greater awareness of sexual theologies; of not seeing sexuality as a "bolt-on" experience but as intrinsic to being human; clarity about the intended purpose of sexuality; embracing sexuality in the context of an incarnational theology; sexual ethics moving from act-centred to the relational; an understanding of the church as a sexual community as opposed to understanding the church as asexual; understanding sexuality in terms of being both personal and communal as opposed to private.

These realisations are necessary in the light of the injured credibility of the church. This may come as a surprise, but the research participants made extensive comments arguing that, if the whole of the previously privileged Afrikaner churches in South Africa could be wrong about apartheid, promoting and justifying it from the Bible, then the church might as well be wrong about sexual conduct. Theological inconsistency, now not about apartheid but sexual morality, helps aggravate this experience of people. While these kind of questions and debates will surely carry on "...the church should be guiding in a positive, value-oriented, open and consistent manner (Selling 2001:160). In doing this, the church should take note that we are living in an imperfect world, and accept the difference between ideal and optimal ethics that takes into account the inability of human nature. Often, however, the ideal is emphasised over against the optimal. "Notwithstanding the desire to uphold an ideal of loving, committed relationships (usually in a marital context) to embody sexual ethics, the fact is that we do not live in a world of ideals. What is worse is that the reality of the world that we do live in is usually not addressed directly" (Selling 2001:159).

\subsection{Parents}

"The formation of norms and values takes place not in isolation but within society, communities and peer-groups. The way people learn is through example and by social understanding" (Nel 1998:394), and parents seems to make an invaluable addition to value-formation.

This article suggests that conscience, a sense of right and wrong, is formed by what parents say, even more importantly how they say it, and what they convey by shying away from much needed open discussion that most effectively entail sharing of personal experience. In the last case what happens is: "When we don't talk about sexuality, we reinforce media images of it as separate from spirituality. The gap between sexua- 
lity and spirituality (spirit-body dualism) is a place where shame grows" (McClintock 2001:12). We agree with McClintock (2001:56-57) when she says:

We can teach our children about sexuality and biblical moral standard by emphasizing love, commitment, and consequence. We don't need to shame them in order to teach them. We can teach them to value good communications in sex by the way we ourselves communicate with them about sex... Being responsible about one's sexuality involves self-awareness, the freedom to say no, and the obligations that go along with saying yes.

This highlights the need to start renegotiating our description of what exactly responsible behaviour is. Responsible behaviour cannot be judged anymore by primarily following prescriptions and rules.

\section{CONCLUDING REMARKS}

We have played the game of snakes and ladders for ages in our communities, institutions and different cultures. Every aspect of this game required social interaction. Even throwing the dice (the contextual circumstances) is a shared activity between society, community, and the individual that moves the snakes (negative discourses) around on the board to church aisles, schoolyards, and family reunions. We cannot close our eyes; snakes are everywhere. Get rid of them? Never! In spite of the fact that we have learned that their power lies in crawling around unnoticed in the corners of our minds, the interpretation of our experiences. Being aware of them has led us to the last square on the board, where we arrived at different descriptions of sex, sexuality and marriage, and realising its implications and our responsibility.

\section{Consulted literature}

Alpaslan, N 1997. Methods and means for a meaningful marriage: A Preparation for marriage and marriage guidance workbook. Pretoria: Kagiso Publishers.

Anderson, H et al (eds), 1998. The Family Handbook. Louisville, Ky: Westminster John Knox.

Barnard, R 2000. Dis tyd dat Christene anders Dink en Praat oor Seks? Wellington: Hugenote-Uitgewers.

Baron, R A \& Byrne, D 1997. Social Psychology. $8^{\text {th }}$ ed. Boston: Allyn and Bacon.

Barton, S C 1998. 'Glorify God in your bodies' (1 Corinthians 6.20): Thinking theologically about sexuality, in Hayes, M A Porter, W \& Tombs. (eds), Religion and Sexuality. Studies in Theology and Sexuality, 2. Roehampton Institute London Papers, 4. London: Sheffield Academic Press, 366-369.

Boesak, A A 1984. Black and Reformed: Apartheid, liberation and the Calvinist tradition, New York: Seabury. 
Bowman, H A \& Spanier, G B 1978. Modern marriage. $8^{\text {th }}$ ed. New York: McGrawHill Book Company.

Bruner, E 1986. "Experience and its expressions", in: Turner, V \& Bruner, E (eds), The Anthropology of Experience. Chicago: University of Illinois Press, 3-20.

Bruner, J 1986. Actual minds/possible worlds. Cambridge: Harvard University Press.

Caputo, J D 1993. Against ethics, in: Studies in continental thought. United States of America: Library of Congress.

Cahill, L S 2001. Sexuality: Personal, Communal, Responsible, in: Selling, J A (ed), Embracing sexuality: Authority and experience in the Catholic Church. Burlington USA: Ashgate Publishing Company.

Carette, J R 1999. Religion and Culture. New York: Routledge.

Carpenter, L M 2001. The First Time/Das Erstes Mal. Approaches to virginity loss in U.S. and German Teen magazines. Youth \& Society 33(1).

Clack, B 1998. Virgins and Vessels: Feminist reflections on dominant models of spirituality, in: Hayes, M A Porter, W \& Tombs, D (eds), Religion and Sexuality. Studies in Theology and Sexuality, 2. Roehampton Institute London Papers, 4. London: Sheffield Academic Press, 193-202.

Derrida, J 1997. Deconstruction in a Nutshell: A Conversation with Jacques Derrida, in: Caputo, J D (ed), Deconstruction in a Nutshell. New York: Fordham University Press.

Dominian, D 2001. Sexuality and Interpersonal Relationships, in: Selling, J A (ed), Embracing sexuality: Authority and Experience in the Catholic Church. Burlington USA: Ashgate Publishing Company.

Donnelly, D A 1993. Sexually Inactive Marriages. The Journal of Sex Research 30(2), 171-179.

Foucault, M 1992. The Use of Pleasure. Harmondsworth: Penguin Books.

Foucault, M 1999. "Sexuality and Power", translated by Lynch, R A, in: Carrette, J R (ed), Religion and Culture. New York: Routledge, 115-30.

Freedman, J \& Combs, G 1996. Narrative Therapy: The Social Construction of Preferred Realities. New York: W.W. Norton and Company.

Gerdes, L C et al 1998. Vroeë en Middelvolwassenheid, in: Louw, D A, Van Ede, D M \& Louw A E (eds), Menslike Ontwikkeling. $3^{\mathrm{e}}$ uitg. Kaapstad: Kagiso Tersiêr.

Gergen, K J 1999. An Invitation to Social Construction. London: SAGE.

Gerkin, C V 1991. Prophetic Pastoral Practice. A Christian Vision of Life Together. Nashville: Abington.

Greeley, A 1973. The New Agenda. Garden City: Doubleday and Co.

Greenberg, B 1998. Marriage: A Jewish Perspective, in Anderson, $\mathrm{H}$ et al (eds), The Family Handbook. Louisville, Ky: Westminster John Knox.

Grey, M. 2001. The Female Experience of Sexuality, in: Selling, J A (ed), Embracing sexuality: Authority and experience in the Catholic Church. Burlington USA: Ashgate Publishing Company. 
Grey, M \& Selling, S 2001. Marriage and Sexuality in the Catholic Church, in Selling, J A (ed), Embracing Sexuality: Authority and experience in the Catholic Church. Burlington USA: Ashgate Publishing Company.

Hanigan, J P 1982. What are they saying about sexual morality? USA: Paulist.

Hare-Mustin, R 1978. Discoursess in the mirrored room: A Postmodern Analysis of Therapy. Family Process 33, 19-35.

Hauerwas, S 1991. After Christendom? Sydney: Anzea.

Hayes, M A 1998. Sexuality and Spirituality: Embattled enemies or kissing cousins? in: Hayes, M A Porter, W \& Tombs, D (eds), Religion and Sexuality: Studies in Theology and Sexuality, 2. Roehampton Institute London Papers, 4. London: Sheffield Academic Press, 240-247.

Hayes, M A, Porter, W \& Tombs, D (eds), 1998. Religion and Sexuality: Studies in Theology and Sexuality, 2. Roehampton Institute London Papers, 4. London: Sheffield Academic Press.

Hobbs, J 1998. Paper Prophets: A treasury of quotations about writers and writing. Goodwood: Zebra Press.

Jordan, M D 2001. The Ethics of Sex: New Dimensions to Religious Ethics. USA: Blackwell Publishers.

Kitzinger, C 1987. The Social Construction of Lesbianism. London: SAGE.

Lamott, A 1995. Bird by Bird: Some Instructions on Writing and Life. New York: Anchor Books.

Louw, D A, Van Ede, D M \& Louw, A E (eds), 1998. Menslike Ontwikkeling. $3^{\mathrm{e}}$ uitg. Kaapstad: Kagiso Tersiêr.

McClintock, K A 2001. Sexual Shame: An urgent call to healing. Minneapolis: Fortress Press.

Miller, E 1993. From Dependency to Autonomy: Studies in organization and change. London: Free Association Books.

Mugerauer, R 1995. Interpreting environments: Traditions, Deconstruction, Hermeneutics. United States of America: University of Texas Press.

Müller, J 1996. Om tot Verhaal te kom. Pretoria: RGN.

Müller, J, Van Deventer, W \& Human, L 2001. Fiction Writing as Metaphor for Research: A Narrative Approach. Practical Theology in South Africa 26(2).

Nel, F B O 1998. An Ecological Approach to the Quest for New Horizons in the Christian View of Sexuality, in: Hayes, M A, Porter, W \& Tombs, D (eds), Religion and Sexuality. Studies in Theology and Sexuality, 2. Roehampton Institute London Papers, 4. London: Sheffield Academic Press, 380-404.

Nelson, J 1996. "Reuniting Sexuality and Spirituality", in: Thatcher, A \& Stuart, E (eds), Sexuality and Gender. Leominster, Herefordshire: Gracewing/Fowler Wright Books, 214-219.

Nicol, J 1989. Naak en Naby: Verhoudingsgroei vir verloofdes en getroudes. Pretoria: HAUM-Uitgewers. 
O'Connel, J 2001. The Catholic Church and Sexuality: The Tensions of Love, Freedom and Law, in: Selling, J A (ed), Embracing sexuality: Authority and experience in the Catholic Church. Burlington USA: Ashgate Publishing Company.

Pato, L L 1997. "Being Fully Human: From the Perspective of African Culture and Spirituality". Journal of Theology for Southern Africa 97, 53-61.

Pienaar, H E 2002. A Social Constructionist Narrative understanding of Sexual Morality. Unpublished MA-dissertation, University of Pretoria, Pretoria.

Rall, W J 1984. A Comparison of married and living-together couples. Unpublished MA thesis, University of South Africa, Pretoria.

Roper, A 2001. A Young Person's Perspective on Authority and Sexuality, in: Selling, J A (ed), Embracing Sexuality: Authority and experience in the Catholic Church. Burlington USA: Ashgate Publishing Company.

Rubin, J \& Rubin, S 1995. Qualitative Interviewing: The Art of Hearing Data. London: SAGE.

Schreiter, R J 1984. Constructing local theologies, New York: Orbis.

Selling, J A (ed), 2001b. Embracing sexuality: Authority and experience in the Catholic Church. Burlington USA: Ashgate Publishing Company.

Selling, J A 2001a. The Development of Catholic Tradition and Sexual Morality, in: Selling, J A (ed), Embracing sexuality: Authority and experience in the Catholic Church. Burlington USA: Ashgate Publishing Company.

Smedes, L B 1983. Mere Morality: What God expects of ordinary people. Grand Rapids, Michigan: William B. Eerdmans Publishing Company.

Smit, D J 2000. Social transformation and confessing the faith? Karl Barth's view on confession revisited. Scriptura 72, 76-86.

Sprecher, S, Barbee, A \& Schwartz, P 1995. "Was it Good For You, Too?" Gender differences in first sexual intercourse experiences. The Journal of Sex Research $32(1), 3-15$.

Tarnas, R 1996. The Passion of the Western Mind: Understanding the ideas that have shaped our World View. Pimlico ed. USA: Crown.

Thatcher, A 1999. Marriage after Modernity: Christian Marriage in Postmodern Times. New York: Shefield Academic Press.

Thatcher, A \& Stuart, E (eds), 1996. Sexuality and Gender. Leominster, Herefordshire: Gracewing/Fowler Wright Books.

Thielicke, H 1964. The Ethics of Sex, translated by Doberstein, J W, London: James Clark.

Thom, D A et al (eds),1998. Adolessensie, in: Louw, D A, Van Ede, D M \& Louw A E (eds), Menslike Ontwikkeling. $3^{\mathrm{e}}$ uitg. Kaapstad: Kagiso Tersiêr.

Turner, V \& Bruner, E (eds), 1986. The Anthropology of Experience. Chicago: University of Illinois Press.

Van Elfen, J 1987. Liefde en Seks in die Huwelik. Kaapstad: Tafelberg Uitgewers Beperk. 
White, M 2000. Reflections on Narrative Practice: Essays \& Interviews. Adelaide South Australia: Dulwich Centre Publications. 